\title{
MENUNDUKKAN BIROKRASI: MELACAK PERTARUNGAN KUASA DIBALIK WACANA REFORMASI BIROKRASI
}

\author{
Caroline Paskarina \\ e-mail: cpaskarinàyahoo.com
}

\begin{abstract}
ABSTRAK
Tulisan ini menempatkan reformasi birokrasi sebagai pertarungan kekuasaan yang bersifat diskursif, dimana ada berbagai argumen yang berebut klaim kebenaran untuk membentuk sosok birokrasi yang profesional. Pendekatan diskursus dipakai untuk menunjukkan bahwa reformasi birokrasi tidak cukup dipahami sebagai praktik manajerial karena pilihan terhadap pendekatan reformasi merupakan pilihan politikyangmencerminkan perset ujuan padarasionalitas tertent udibalikpendekat an tersebut. Analisis diskursus terhadap konsep-konsep yang menjadi arus besar dalam reformasi birokrasi menunjukkan bahwa reformasi birokrasi berupaya menundukkan birokrasi untuk patuh pada rezim pasar, yang kemudian melahirkan sosok birokrasi dengan cara kerja yang sejalan dengan kehendak rezim tersebut. Hal ini penting diungkapkan untuk menumbuhkan kesadaran bahwa konsep reformasi birokrasi tidak netral tapi senantiasa mengandung kepentingan untuk berkuasa. Di sisi lain, kesadaran ini membuka peluang bagi proses diskursif berkelanjutan untuk merumuskan sosok birokrasi alternatif yang disesuaikan dengan konteks politik yang ada dalam organisasi publik.
\end{abstract}

Kata kunci: diskursus reformasi birokrasi, penundukkan birokrasi.

\section{ABSTRACT}

This paper analyzed bureaucratic reform as discursive power struggle, in which there are various arguments are contesting the truth claims to construct professional bureaucracy. Discourse approach is used to indicate that the reform of bureaucracy is not merely a managerial practices because the choice of approach to reform is a political choice that reflects the specific approval of the rationality behind the approach. Through the analysis of mainstream concepts of bureaucratic reform indicates that bureaucratic reforms has become instrument of power to subject bureaucracy under the regime of market friendly, which gave birth to the figure of bureaucracy that behave according to the regime's code of conduct. It is 
important to raise awareness that the concept of bureaucratic reform is not neutral but always reflect the interests to conquer bureaucracy. On the other hand, this awareness also opens the opportunities for ongoing discursive process to formulate alternative bureaucracy figure adjusted to the existing political context within public organizations.

Keywords: discourse of bureaucratic reform, bureaucracy subjectivation.

\section{PENDAHULUAN}

Pembahasan tentang birokrasi selalu memicu perdebatan karena kehadirannya masih tetap dianggap penting kendati banyak pula yang mengkritisi lambannya kinerja birokrasi yang diakibatkan oleh kepatuhan birokrasi yang kadang dianggap berlebihan terhadap prosedur kerja. Keluhan terhadap kinerja birokrasi terutama muncul dalam kapasitasnya untuk menyediakan pelayanan publik dengan efektif dan efisien. Bahkan, keberadaan birokrasi pun seringkali dikaitkan dengan praktik-praktik koruptif yang terjadi dalam lingkungan pemerintahan. Berbagai permasalahan tersebut menjadi awal berkembangnya wacana perubahan birokrasi, yang bertujuan mengubah cara kerja birokrasi menjadi lebih efektif dan efisien sehingga dapat memberikan pelayanan publik dengan lebih optimal.

Kendati wacana reformasi birokrasi baru berkembang setelah berakhirnya era Orde Baru, tapi tuntutan akan birokrasi yang profesional sesungguhnya telah ada di Indonesia dan memperoleh momentum ketika pembangunan menjadi orientasi utama dalam penyelenggaraan pemerintahan. Pembangunan yang bertumpu pada pertumbuhanekonomidanpeningkatan pendapatan perkapita mensyaratkan alokasi sumber-sumber daya dilakukan secara terencana dengan menggunakan perhitungan-perhitungan objektif agar tujuan dapat dicapai dengan seoptimal mungkin. Penyelenggaraan pemerintahan yang sentralistik dianggap lebih dapat mewujudkan efektivitas dan efisiensi dalam upaya mencapai kesejahteraan. Apalagi, dalam paradigma pembangunan yang menitikberatkan pada modernisasi dan pertumbuhan ekonomi, peran pemerintah sebagai aktor utama yang mengarahkan proses pembangunan mensyaratkan sentralisasi kewenangan agar peran pemerintah tersebut dapat diterapkan dengan efektif. Tapi, kewenangan yang serba terpusat ternyata memunculkan efek negatif yang menyebabkan praktik kekuasaan menjadi otoriter. Di sisi lain, semakin pesatnya perubahan sosial menyebabkan kapasitas pemerintah mulai menurun (Fukuyama, 2005). Sentralisasi dalam penyelenggaraan pembangunan ternyata tidak sepenuhnya mampu mewujudkan pemerataan dan keadilan 
bagi mayoritas warga masyarakat untuk mencapai akses yang sama terhadap pertumbuhan ekonomi yang dicapai.

Pertengahan dekade 1980-an, sentralisasi dan dominasi peran negara mendapat kritik karena menyebabkan mahalnya biaya penyelenggaraan negara (Peters, 2002). Kaum liberal menawarkan alternatif deregulasi, debirokratisasi, dan privatisasi sebagai bagian dari upaya mereformasi birokrasi. Upaya-upaya tersebut diyakini dapat menciptakan suasana yang kondusif bagi pasar karena dengan meminimalkan intervensi negara, maka pasar dapat bergerak lebihleluasa untukmelakukan berbagai aktivitas ekonomi. Ketika konsep ini diterapkan, pertumbuhan ekonomi memang menjadi lebih cepat (Fukuyama, 2005), tetapi penurunan peran negara juga menyebabkan kelompok-kelompok masyarakat dengan kemampuan ekonomi terbatas kesulitan untukmemperoleh pelayanan publik yang berkualitas (Ayres dan Braithwaite, 1992; Cope, 1997). Hal ini menyebabkan menurunnya legitimasi negara di mata publik karena mengindikasikan ketidakmampuan negara dalam memenuhi kesejahteraan publik. Kondisi ini kembali memunculkan perdebatan tentang bagaimana seharusnya reformasi birokrasi dilakukan untuk mengatasi komersialisasi dan marginalisasi yang muncul sebagai ekses negatif dari reformasi birokrasi pro-pasar.
Pendulum reformasi birokrasi kembali bergeser unt uk mencari sosok birokrasi yang dapat menjawab tantangan tersebut.

Setiap pendekatan dalam reformasi birokrasi senantiasa berupaya membentuk birokrasi untuk patuh pada cara kerja pendekatan tersebut. Asumsi ini menjadi alasan untuk mengkaji reformasi birokrasi sebagai praktik kekuasaan. Bukan praktik kekuasaan yang tercermin dari relasi antaraktor, melainkan dari pertarungan wacana unt uk membentuk klaim kebenaran yang melandasi pilihan politik dibalik setiap pendekatan. Untuk mengungkapkan praktik diskursif tersebut, tulisan ini terlebih dahulu akan membahas birokrasi sebagai konstruksi realitas yang tidak hanya memunculkan idealisasi sosok birokrasi tapi juga problematisasi dari sosok birokrasi yang dianggap tidak memenuhi idealisasitersebut.Selanjutnya, dengan menguraikan konsep-konsep yang menjadi arus utama (mainstream) dalam reformasi birokrasi, akan diungkapkan kepentingan kekuasaan untuk menundukkan birokrasi. Tulisan ini ditutup dengan kemungkinankemungkinan yang dapat dipakai sebagai peluang untuk menumbuhkan kesadaran akan hegemoni wacana reformasi birokrasi serta apa yang dapat dilakukan untuk memanfaatkan peluang tersebut. 


\section{Birokrasi sebagai Konstruksi Realitas}

Kehadiran birokrasi tidak dapat dilepaskan dari modernitas, bahkan seringkali keberadaannya menjadi simbol dari modernitas itu sendiri (Harris, Clegg, dan Hopfl, 2011). Modernitas secara umum diartikan sebagai kondisi sosial yang ditandai dengan rasionalitas sebagai penjelas dari dinamika kehidupan masyarakat. Rasionalisasimerujukpadageneralisasi dari rasionalitas teknis yang mewujud dalam bentuk kalkulasi dan kontrol at as proses-proses sosial dengan tujuan mengoptimalkan efisiensi (Feenberg, 2003).

Hasrat rasionalisasiyangmewujud kedalam pengaturan segala hal dengan menggunakan perhitungan-perhitungan ilmiah dan teknologi memunculkan individu dengan identitas baru, sebagaimana dikatakan Weber, yakni individu-individu yang terbebas dari belenggu ideologi dan dogma religi (Feenberg, 2003). Kapitalisme awal mengubah struktur sosial dengan memunculkan kelas menengah dari kalangan pekerja, yang tidak lagi terikat dengan norma-norma paternalistik. Berkembangnya mekanisme pasar memberikan beragam alternatif bagi individu untuk memenuhi kebutuhannya, dan dengan begitu individu didorong untuk mengoptimalkankemampuanrasionya. Modernitas melahirkan individuindividu yang bebas dan otonom dalam mengelola berbagai urusannya.
Implikasi berikutnya dari rasionalisasi adalah pemilahan masyarakat ke dalam kategori-kategori dikotomis, seperti alamiah versus ilmiah, tradisional versus modern, privat versus publik, agama versus negara, dan seterusnya. Pemilahan ini cenderungmenyederhanakankompleksitas dan mengarahkan perubahan sosial ke dalam proses yang linear dimana posisi yang dituju dianggap lebih baik ketimbang posisi awal. Sebagai produk dari modernitas, birokrasi pun lahir dari logika dikotomi tersebut. Birokrasi dalam konsepsi Weber, lahir sebagai alternatifterhadap pengelolaan urusan-urusan publik yang sebelumnya menggunakan caracara irasional yang sarat dengan pendekatan kekuasaan. Efektivitas dan efisiensi yang diperlukan bagi bekerjanya kapitalisme menghendaki berbagai urusan dikelola secara rasional, sehingga birokrasi muncul sebagai model organisasi yang mengedepankan rasionalitas teknis.

Birokrasi, menurut Weber (dalam Said, 2010), adalah sistem administrasi rutin yang dilakukan dengan keseragaman, diselenggarakan dengan cara-cara tertentu, didasarkan aturan tertulis, oleh orang-orang yang berkompeten di bidangnya. Sejalan dengan pendapat tersebut, Rourke (dalam Said, 2010) mengatakan bahwa birokrasi adalah sistem administrasi dan pelaksanaan tugas keseharian yang terstruktur, dalam sistem hirarkhi yang jelas dilakukan dengan aturan tertulis, dilakukan oleh bagian tertentu yang 
terpisah dengan bagian lainnya, oleh orang-orang yang dipilih karena kemampuan dan keahlian di bidangnya. Keduapendapat tersebut menggambarkan birokrasi sebagai cara atau metode pengorganisasian kerja yang digerakkan oleh orang-orang yang memiliki keterampilan, pengalaman, dan keahlian. Birokrasi mengatasi masalah dalam organisasi, yakni bagaimana memaksimalkan efisiensi dalam organisasi. Untuk mencapai tujuantersebut, Webermengungkapkan bahwa birokrasi harus didukung oleh sistem otoritas legal, yang meliputi: pengaturan tugas-tugas pejabat atas dasar aturan yang berkesinambungan; pembagian tugas-tugas tersebut atas bidang yang berbeda sesuai dengan fungsinya, yang masing-masing dilengkapi dengan syarat tertentu; jabatan tersusun secara hirarkhis, yang disertai dengan rincian hak-hak kontrol dan pengaduan; aturan disesuaikan dengan pekerjaan, diarahkan baik secara teknis maupun secara legal. Dalam hal tersebut, manusia yang terlatih menjadi diperlukan untuk menjalankan sistem administrasi unt uk mencapai tertib organisasi.

Di sisi lain, ada juga konstruksi birokrasi yang memandangnya secara negatif. Birokrasi dikritik karena berbagai penyakit yang muncul di tubuh birokrasi, seperti lamban, berbelit-belit, kaku, rentan dengan politisasi, dan sebagainya. Gambaran ini sangat berbeda dengan idealisasi ala Weber tentang birokrasi sebagai sosok organisasi modernyang obyektif, impersonal, dan bekerja dengan serba terukur. Pertentangan cara pandang ini menjadikan kajian birokrasi lebih banyakmembahas bagaimanabirokrasi diubah dari sosoknya yang negatif. Padahal, cara pandang dikotomis tersebut mengabaikan kompleksitas realitas yang direpresentasikan oleh birokrasi.

Styhre (2007) membuat 3 (tiga) klasifikasi pemaknaan birokrasi yang selama ini berkembang. Pertama, birokrasi selalu dikesankan secara negatif sebagai organisasi yang tidak efisien, kinerjanya tidak memuaskan publik, dan para anggotanya tidak memiliki pengalaman kerja yang menunjang kompetensinya. Kedua, birokrasi juga sering digambarkan sebagai bentuk organisasi primordial yang kinerjanya buruk. Ketiga, karena birokrasi seringkali diasosiasikan dengan formasi sosial yang menghendaki lingkup intervensi sektor publik yang besar serta administrasi publikyang tertutup terhadap kekuatan pasar dan kompetisi, birokrasi juga sering dikritik sebagai predatory capitalism yang menghalangi munculnya ideologi kemandirian, individualisme, dan jenjang karir berbasis meritokrasi. Ketigaklasifikasi tersebut menempatkan birokrasi dalam identitas yang cenderung negatif, sebagai organisasi yang tidak responsif terhadap perubahan karena telah ada mekanisme internal yang menjamin keberlangsungan hidup organisasi dan para anggotanya. Jenjang karir dapat diprediksikan karena ada mekanisme 
hirarkhi yang menjamin kenaikan karir, seringkali tanpa mempertimbangkan kualitas kinerja yang dihasilkan. Demikian pula, insentif berupa pendapatan dan tunjangantunjangan relatif terjamin karena ada standar yang memungkinkan setiap aparat birokrasi memperoleh bagian dari pendapat an dan tunjangan tersebut sesuai dengan kedudukannya dalam organisasi.

Cara kerja birokrasi yang terikat pada ketertiban aturan, prosedur, dan rantai komando menjadikan birokrasi sebagai institusi yang bergant ung pada perintah dari hirarkhi yang lebih tinggi. Keberhasilan kinerja birokrasi diukur dari kemampuannyamencapai standarstandar yang ditentukan oleh penguasa untuk mempertahankan loyalitas birokrasi. Dalam sistem ini, orientasi kerja birokrasi adalah kepada atasan, bukan kepada publik yang seharusnya dilayaninya, yang pada akhirnya menjadikan birokrasi sebagai instrumenkekuasaan untukmembentuk kepatuhan publik pada kewenangan negara.

Problematisasi terhadap identitas birokrasi tidak hanya disebabkan oleh kesan negatif yang muncul tapi juga dari ketunggalan identitas tersebut. Konsep birokrasi sebagai tipe ideal organisasi modern, sebagaimana dikemukakan oleh Weber, menjadi penyebab ketunggalan identitas birokrasi, sehingga ketika pada praktiknya birokrasi tidak bekerja sebagaimana identitas ideal itu maka kesan negatif yang muncul. Penggambaran birokrasi sebagai sosok negatif yang harus diubah menjadi sosoklainyanglebihbaikmenempatkan birokrasi sebagai sasaran penundukkan demi menciptakan sosok birokrasi yang sesuai dengan penggambaran birokrasi yang baik.

\section{Narasi Besar Reformasi Birokrasi}

Gagasan reformasi birokrasi berkembang sebagai respon terhadap citra negatif birokrasi.Organisasi birokrasi diproblematisasi sebagai organisasi yang lamban, 'gemuk', dan banyak menyerap anggaran tapi gagal berfungsi optimal (Peters, 2002). Besarnya biaya birokrasi dalam pandangan Niskanen disebabkan oleh monopoli informasi oleh birokrasi, sehingga untuk menjadikan birokrasi lebih efisien, harus ada informasi alternatif yang dapat diakses oleh pengambil kebijakan (dalam Peters, 2002). Untuk mengontrol birokrasi, Niskanen menyarankan agar mekanisme pasar digunakan, dengan memberi peluang bagi organisasiorganisasi lain untuk menyediakan jenis-jenis pelayanan seperti yang biasanya dilakukan birokrasi. Melalui praktik ini, birokrasi didorong untuk lebih efisien dalam bekerja karena ia akan senantiasa berhadapan dengan pesaingnya. Meskipun dampak dari praktik ini kemudian menuai kritik karena memunculkan masalah baru, yakni komersialisasi pelayanan publik, 
tapi pemikiran tentang adopsi cara kerja pasar, khususnya kompetisi, telah memunculkan identitas baru birokrasi sebagai sosok yang market friendly.

Sejumlah literatur yang beredar pada awal abad ke-20 menawarkan gagasan reformasi birokrasi dengan meminjam praktik-praktik yang biasanya digunakan dalam organisasi privat. Cara kerja lama yang berbasis hirarkhi dipermasalahkan, sehingga harus diganti dengan cara kerja berjejaring. Struktur yang merupakan cerminan dari simpul-simpul rantai komando, digantikan oleh unit-unit kerja yang mencerminkan fungsi. Demikian pula, kepatuhan birokrasi pada tertib prosedur, digantikan oleh kepatuhan pada standar kinerja yang menjadi ukuran keberhasilan birokrasi dalam menjalankan fungsinya. Birokrasi pemerintah diarahkan menjadi organisasi yang lebih berorientasi pada optimalisasi kinerja, pencapaian hasil yang serba terukur, berupaya mencapai kepuasan pengguna, dan seterusnya yang mengharuskan birokrasi untuk mengubah bentuk, struktur, proses kerja, bahkan budaya organisasinya.

Diskursus
mempertanyakan ulang
kebenaran bahwa birokrasi adalah
satu-satunya aktor yang memiliki
kewenangan untuk menentukan
pengelolaan sumber daya atas nama
negara. Ketidakmampuan birokrasi
untuk bersikap proaktif terhadap
dinamika perubahan menjadi dasar

argumentasi bagi diskursus pro-pasar untuk mendekonstruksi birokrasi, dengan cara mendelegitimasi kapasitas birokrasi dalam mengelola sumber daya secara efektif dan efisien. Problematisasi kapasitas birokrasi inilah yang mengawali pembentukan ulang birokrasi sebagai subjek yang pro-pasar, dengan nilai dan cara kerja baru yang mengadaptasi prinsipprinsip pro-pasar.Nilai-nilai baru yang masuk ke dalam tubuh birokrasi merupakan bagian dari proses diskursif neoliberalisme yang mewacanakan urgensi penyesuaian struktural dalam institusi-institusi negara, termasuk birokrasi, dalam rangka melayani kepentingan pasar (Springer, 2010; Mok, Ka-Ho, dan Forrest, 2009).

Dalam konteks neoliberalisme yang berkembang pada dekade 1990an, pengetahuan menjadi penciri yang membedakan masyarakat industri dengan masyarakat pascaindustri. Masyarakat pascaindustri adalah masyarakat yang menggunakan pengetahuan sebagai basis pengambilan keputusan (Castells, 2004). Pertimbangan yang digunakan untuk menentukan tindakan juga tidak sekedar diorientasikan pada optimalisasi manfaat, tapi seberapa besar resiko yang dapat dikelola. Pengetahuan menjadi sumber daya yang dipakai untuk menghitung resiko, sehingga kemampuan unt uk mengelola pengetahuan menjadi hal strategis pada masa ini.

Pengetahuan menjadi sumber 
daya untuk membentuk pemahaman baru tentang berbagai hal dan menerapkannya pada teknologi, produk, atau proses tertentu. Kapabilitas intelektual dan keterampilan mental menjadi semakin penting bagi penciptaan kesejahteraan, menggantikan keterampilan-keterampilan fisikdan kontrol birokratis atas sumbersumber daya. Intelektualitas juga menjadi prasyarat penting untuk merespon secara kreatif berbagai kondisi ketidakpastian. Kreativitas ini dihasilkan melalui pengelolaan pengetahuan, yang pada dasarnya mencakup aktivitas-aktivitas penciptaan, penyebaran, dan pemanfaatan pengetahuan (Wikstrom dan Norman dalam Blacker, Crump, dan McDonald, 1998). Karena itu, sumber daya manusia yang dapat melakukan fungsi ini adalah mereka yang mampu menggunakan semaksimal mungkin keunggulan kompetitif dari pengetahuan yang dimilikinya untuk menghasilkan sesuatu yang baru atau berbeda dari yang sudah ada sebelumnya.Drucker (1993) menjelaskan bahwa dinamika ekonomi di negara-negara Barat pada masa sekarang telah bergeser dari ketergantungan pada keterampilan teknis menjadi kemampuan kreatif dari para knowledge workers, yakni people who are able to exploit the competitive advantage that their specialized insights provide (dalam Blacker, Crump, dan McDonald, 1998). Dengan demikian, pengelolaan pengetahuan tidak hanya mencakup aktivitas pengelolaan data, tapi juga pembentukan subjek yang dapat melakukan aktivitas-aktivitas tersebut.

Kebutuhan untuk mengelola pengetahuan mensyaratkan adanya kreativitas dan inovasi karena esensi dari pengelolaan pengetahuan adalah kemampuan untuk memaknai data dalam rangka membentuk realitas. Pembentukan realitas adalah proses kreatif yang mensyaratkan individuindividu yang mampu berpikir bebas. Karena itu, struktur birokrasi konvensional yang hirarkhis perlu diubah agar individu-individu tidak lagi terbatasi oleh hirarkhi tersebut. Birokrasi didekonstruksi melalui penyebaran konsep reinventing government (Osborne dan Gaebler, 1993), banishing bureaucracy (Osborne dan Plastrik, 1998), privatization(Savas, 1987), enterpreneurship bureaucracy(Hjorth, 2003), innovative bureaucracy(Styhre, 2007), dan sejenisnya yang menonjolkan sosok birokrasi sebagai organisasi yang bekerja dengan memaksimalkan kemampuannya untuk mengelola pengetahuan untuk menciptakan inovasi dalam pelaksanaan fungsifungsinya.

Konsep-konsep tersebut menjadi narasi besar yang mendasari praktik reformasi birokrasi di berbagai negara. Reinventing government dari Osborne dan Gaebler menjadikan reformasi birokrasi sebagai proses untuk membentuk birokrasi pemerintahan 
yang memiliki karakter entrepreneur. Dengan menerapkan entrepreneurship, birokrasi dapat menghemat anggaran dan merespon tuntutan publik dengan lebih baik dengan mengubah cara kerja organisasinya, khususnya melalui perbaikan dalam sistem penganggaran. Nilai lebih yang ditawarkan dari konsep ini adalah bahwa dengan menghemat penggunaan anggaran, maka pimpinan organisasi dapat memperoleh anggaran non-budgeter untukdigunakanmemenuhikebutuhankebutuhan yang lebih penting demi mengoptimalkan produktivitas organisasi. Meskipun ada sisi positif ini, konsep reinventing government juga mengandung potensi masalah karena menurunkan responsivitas politik dari organisasi pemerintah. Sistem penganggaran merupakan proses politik, ketika birokrasi melakukan perubahan dalam alokasi anggaran atau menggunakan anggaran yang tidak tercant um dalam kebijakan penganggaran, maka birokrasi telah mengabaikan persetujuan dari para pengambil kebijakan di ranah politik yang merepresentasikan kepentingan publik.

Konsep reinventing government jugamemperkenalkan prinsipcustomer friendly, dimana pemerintah harus responsif terhadap kebutuhan pelanggan. Pelanggan yang dimaksud adalah warga masyarakat. Konsepsi ini mengubah secara mendasar relasi kekuasaan antara pemerintah dan warga masyarakat. Responsivitas kepada pelanggan berbeda dengan responsivitaskepadawargamasyarakat. Responsif kepada pelanggan, artinya perusahaan atau penyedia layanan harus dapat menyediakan produk yang dikehendaki pelanggan, dibuat dengan berkualitas, dengan harga yang paling terjangkau. Pelanggan tidak harus menyukai atau menyetujui produk tersebut karena pelanggan memiliki hak memutuskan dan kemampuan membayar atas produk tersebut, sehingga penyedia layanan justru saling berkompetisi untuk memperoleh pelanggan. Karena itu, kepuasan pelanggan menjadi faktor utama yang memotivasi kinerja penyedia layanan. Hal ini berbeda dengan responsivitas kepada warga masyarakat, dimana penyedia layanan harus menyediakan produk yang dibutuhkan oleh warga masyarakat, dengan kondisi yang disepakati melalui proses politik karena tidak semua warga masyarakat memiliki kemampuan yang sama untuk memperoleh produk tersebut. Pelayanan birokrasi pemerintahan dibiayai melalui pajak yang memiliki sistem paksaan. Karenaitu, pemerintah tidak hanya harus memastikan kepuasan masyarakat dengan menyediakan pelayanan yang terjangkau, tapi juga menyediakan jenis-jenis pelayanan yang diaspirasikan publik melalui wakil-wakil politiknya. Efisiensi ditentukan tidak sekedar melalui insentif bagi organisasi yang mampu melakukan penghematan, tapi juga melalui penurunan pajak bagi publik.

Kemampuan birokrasi juga diukur 
dari kinerjanya, yakni kemampuan birokrasi untuk melaksanakan aktivitas-aktivitasnya dengan efektif dan efisien. Untuk mengukurnya, dibentuk tim evaluator khusus untuk melakukan assessment dan merekomendasikan strategi-strategi agar pemerintahan dapat berjalan dengan lebih efisien. Hasil evaluasi kinerja dijustifikasi oleh pengukuran kuantitatif yang dikembangkan dari metode yang biasanya digunakan untuk melakukan kontrol dalam sistem total quality management dan metodologi evaluasi program yang dikembangkan oleh Sosiologi, Ilmu Politik, dan Analisis Kebijakan Publik (Cope, 1997). Statistik menjadi instrumen yang dipakai untuk memberikan klaim kebenaran terhadap pencapaian kinerja, sekaligus menjadikan proses birokrasi lebih objektif dan terprediksi. Pada gilirannya, pengukuran kuantitatif untuk kinerja birokrasi pun menjadikan birokrasi sebagai subjek yang selalu diawasi dan dikendalikan, sehingga kepatuhannya juga dibentuk oleh angka-angka statistik tersebut.

Konsep reinventing government membentuk ulang birokrasi kedalam sosok organisasi privat yang tunduk pada standar kinerja demi mencapai efektivitas dan efisiensi. Konsep ini menjadikan rasionalitas ekonomi sebagai kerangka pikir untuk membentuk idealisasi birokrasi. Gagasan untuk menjadikan birokrasi menyerupai organisasi privat yang bekerja at as dasar rasionalitas ekonomi memperoleh klaim kebenaran seiring denganbergesernyakajian administrasi publik dari old public administration ke arah new public management. Model old public administration didasarkan pada doktrin pemisahan kekuasaan yang dilakukan melalui pendelegasian sejumlah fungsi kepada para aparat birokrasi pemerintahan untuk melaksanakan kebijakan dengan menggunakan anggaran publik. Prinsip utama dari model ini adalah birokrasi harus independen dari proses politik. Peran birokrasi adalah memberikan pertimbangan rasional tanpa dipengaruhiolehberbagaikepentingan. Netralitas ini dijamin melalui sistem karir dan norma perilaku profesional yang melekat pada institusi birokrasi, seperti halnya tergambar dalam nilainilai ideal birokrasi ala Weber. Penggunaan kata 'management' sebagai pengganti 'administration' telah menggambarkan pergeseran prinsip organisasi dari yang semula berbasiskan regulasi normatif menjadi berbasiskan kinerja. Dalam konsep new public management, birokrasi harus lebih responsif terhadap preferensi warga masyarakat maupun para politisi sebagai pengambil kebijakan. Profesionalitas birokrasi diukur dari kemampuannya untuk merespon preferensi publik secara memuaskan, dan untuk itu, birokrasi dituntut untuk dapat mengelola informasi dengan optimal.

Pengelolaan informasi oleh birokrasi tidak berarti bahwa informasi dikuasai oleh birokrasi, tapi birokrasi 
ditunt ut untukdapat mengolahberagam jenis informasi yang masuk dari berbagai sumber. Ada kapasitas baru yang perlu dimiliki oleh birokrasi, dan unt uk itu, yang menjadi sasaran adalah individu. Individu yang kemudian dilatih untuk punya kemampuan mengumpulkan, menyimpan, dan menyajikan data sebagai bahan pengambilan keputusan. Osborne dan Gaebler (dalam Hjorth, 2003) menegaskan bahwa kunci penentu keberhasilan transformasi birokrasi adalah dengan menanamkan kultur entrepreneur dalam diri birokrasi agar kinerja organisasi menjadi lebih efisien dan lebih fleksibel. Kult ur entrepreneur yangdimaksudadalahmemperkenalkan nilai-nilai korporasi dimana tanggungjawab setiap pegawai dibentuk atas dasar rasionalitas ekonomi dalam bentuk insentif dan bukan komando (Osborne dan Gaebler, 1992; Hjorth, 2003).

Klaim ini diperkuat oleh Milton Friedman (dalam Hjorth, 2003) yang secara tegas mengkritik birokrasi klasik sebagai regulator yang tidak cukup punya kapasitas dan di sisi lain, juga inefisien dalam menjalankan peran distribusi barang dan jasa publik. Sebaliknya dengan mekanisme pasar bebas dan korporasi, birokrasi dapat menyediakan pelayanan yang sesuai dengan kebutuhan konsumen. Kompetisi, seperti juga tawaran Niskanen, dapat mendorong setiap individu untuk bertindak rasional dalam memaksimalkan hasil. Rasionalitas ekonomi ini diperkuat oleh konsep kepemilikan individual yang mengasumsikan bahwa kepemilikan pribadi atas barang dan jasa akan membuat pemanfataan barang dan jasa tersebut lebih efisien. Karena itu, dominasi birokrasi atas alokasi barang dan jasa atas nama kewenangan negara harus diminimalkan atau dialihkan melalui mekanisme privatisasi.

Selain pergeseran dalam mode pengelolaan barang dan jasa publik, rasionalitas ekonomi juga memberi makna baru dalam pemilahan antara 'buruh' (labor) dan 'pekerja' (worker), di mana 'pekerja' diposisikan lebih baik ketimbang yang pertama karena menjadi sumber daya manusia (human capital) yang dikaitkan dengan proses investasi dan akumulasi kapital ekonomi (Read, 2009). Gaji yang diperoleh pekerja menjadi pendapatan yang didasarkan pada keterampilan atau kemampuan seseorang, sehingga setiap aktivitas yang dapat meningkatkan kapasitas untuk memperolehpendapatandikategorikan sebagai bentuk investasi dalam sumber daya manusia. Dalam rangka memaksimalkan seluruh kapasitas individu untuk kepentingan akumulasi kapital, teknologi dipakai sebagai alat untukmengatasikelemahan-kelemahan fisik manusia. Rasionalitas ekonomi menjadi dasar pertimbangan bagi manusia untuk menjadi entrepreneur, yakni entrepreneur at as dirinya sendiri. Neoliberal menjadi rezim kebenaran yang membentuk subjek baru, yakni homo economicus yang dibentuk atas 
dasar motivasi dan diatur oleh prinsipprinsip rasionalitas ekonomi (Read, 2009).

Konsep utama lainnya yang membentuk narasi besar reformasi birokrasi adalah good governance, yang dipopulerkan oleh Bank Dunia pada akhir dekade 1980-an hingga awal 1990-an. Governance didefinisikan sebagai sebuah bentuk penggunaan kekuasaan politik untuk mengelola urusan publik (Bank Dunia, 1989). Untuk menjamin agar pengelolaan urusan publik tersebut mencapai hasil pembangunan yang dikehendaki, ditetapkan sejumlah prinsip good governance, antara lain birokrasi yang efisien, sistem peradilan yang independen, penggunaan anggaran publik secara akuntabel, penegakan hukum, pengakuan hakhak asasi manusia, kebebasan pers, dan sebagainya, yang pada intinya merupakan penjabaran dari nilai-nilai demokrasi liberal. Dengan demikian, konsep good governance ini pada dasarnya masih tetap merujuk pada demokrasi liberal sebagaimana diterapkan pula oleh neoliberalisme. Demikian pula dalam konsepsi mengenai peran negara, tidak berbeda dengan neoliberalisme yang menghendaki peran negara seminimal mungkin, bahkan dalam konsep good governance, yang menjadi fokus justru adalah bagaimana mengontrol negara dalam melaksanakan kewenangannya (Fritz dan Menocal, 2006).

Sebagai salahsatu dimensi yang mendukung tercapainya good governance, birokrasi diubah untuk menjadilebihramahterhadap dinamika pertukaran sumber daya yang berbasis efektivitas dan efisiensi. Dalam konsep ini, negara dan birokrasi sebagai mesin politik negara hanya menjadi salahsatu aktor selain pasar dan masyarakat dalam pengelolaan sumber-sumber daya. Untuk menghindari penyimpangan yang mungkin timbul akibat intervensinegara, dibangunmekanisme pengawasan eksternal dan internal terhadap negara yang tergambar dalam konsep-konsep akuntabilitas dan penegakan hukum. Ada 2 (dua) instrumen yang digunakan oleh konsep good governance atau market-friendly state intervention dalam pengelolaan sumber daya, yakni: pertama, kebijakan yang mempromosikan penanganan pengangguran melalui insentif bagi pasar untuk memperluas lapangan kerja serta,kedua, penyediaan pelayanan dasar bagi kaum miskin, seperti pelayanan kesehatan dasar, pendidikan dasar, dan perbaikan gizi (Fritz dan Menocal, 2006). Kedua instrumen ini mencerminkan pembagian peran antara pasar dan negara. Pasar tetap berfungsi sebagai penggerak kegiatan ekonomi, sementara negara lebih berperan untuk menjamin keseimbangan sosial bila mekanisme pasar mengalami kegagalan.

Sebagai kerangka pikir yang mendasari narasi besar reformasi birokrasi, neoliberalisme bekerja atas dasar kepentingan, hasrat, dan aspirasi 
individu. Ia tidak secara langsung memaksa individu untuk berperilaku tertentu, tapi melalui kondisi-kondisi tindakan yang diciptakan untuk mendorong individu berperilaku sesuai dengan tuntutan kondisi tertentu. Dalam kerangka ini, reformasi birokrasi menjadi proses untuk mengubah cara kerja birokrasi dengan mendorong individu untuk bekerja dengan lebih baik, mengoptimalkan potensidirinya, danmemacukreativitas dalam kinerjanya. Dalam upaya mewujudkanindividudengankapasitas seperti itu, konsep reformasi birokrasi mengembangkan berbagai instrumen untuk membentuk birokrasi agar terbiasa melakukan aktivitas-aktivitas yang memungkinkan pelaksanaan tugas menjadi lebih efektif dan efisien, seperti standar kinerja, sistem penganggaran berbasis kinerja, pengukuran kepuasan pelayanan, dan perencanaan strategis berbasis data.

\section{PENUTUP:}

\section{Identifikasi Peluang untuk Melawan Penundukkan}

Kendati neoliberalisme sangat kuat melandasi praktik reformasi birokrasi yang selama ini diterapkan, tapi dalam kenyataannya, birokrasi pun melakukan perlawanan terhadap penundukkan tersebut. Reformasi birokrasi yang digagas oleh konsepkonsep arus utama sebagaimana diuraikan di atas telah membawa cara kerja baru dalam tubuh birokrasi, dan perubahan ini juga turut membuat kinerja birokrasi menjadi lebih baik. Meskipun belum sepenuhnya memuaskan publik, tapi perubahan cara kerja ini membentuk birokrasi menjadi lebih transparan dan akuntabel kepada publik. Keberhasilan ini melahirkan sosok-sosok birokrasi inovatif dan berbagai praktik pelayanan kreatif yang memberikan nilai positifterhadap transformasi yang terjadi. Penilaian positif ini menjadi peluang untuk memasukan kembali responsivitas politik yang direduksi oleh sistem pasar.

Reformasi birokrasi tidak boleh dipandang sebagai proses linear yang semata-mata mengubah birokrasi dari sosok lama yang bermasalah menjadi sosok baru yang profesional. Selalu ada kemungkinan munculnya sosok alternatif yang menggambarkan perpaduan nilai-nilai birokrasi Weber dan nilai-nilai pro-pasar. Berbagai konsep dalam diskursus reformasi birokrasi yang berkembang memiliki banyak 'wajah', sehingga pemilahan yang bersifat dualistik tidak lagi tepat dipakai. Persoalan yang jauh lebih penting adalah mengungkap bagaimana 'wajah-wajah' dari konsep itu mewujud dan cara-cara apa yang dipakai untuk mereproduksi klaim kebenarannya. Ini adalah persoalan pengungkapan cara kerja kekuasaaan yang menentukan bagaimana sesuatu diatur. Diskursus reformasi birokrasi dapat mewujudkan 'wajah' reformis ketika ia melakukan perlawanan terhadapkemapanancarakerjaberbasis hirarkhi dan rutinitas dalam diri birokrasi. Tapi, di sisi lain, reformasi birokrasi juga menjadi diskursus hegemonik ketika ia mereduksi makna 
kebebasan ke dalam batasan-batasan standar. Reformasi birokrasi juga memunculkan 'wajah' teknokratis ketika ia menjadikan mekanisme, ukuran-ukuran kinerja, dan kalkulasi pencapaian target sebagai alat untuk membentuk ulang cara kerja birokrasi, tapi abai terhadap aspirasi publik yang muncul diluar kalkulasi tersebut.

Rezim pasar yang diperkenalkan oleh narasi besar reformasi birokrasi menundukkan birokrasi pada standardisasi. Ini menguatkan tesis Weber yang mengkritik rasionalisasi ekonomi yangmenjebakbirokrasijadi organisasi yang tidak peka pada dimensi moral. Standar-standaryangdibuat merupakan instrumen untuk memaksa dan mengarahkan perilaku birokrasi agar mengikuti kehendak rezim pasar. Persoalannya bukan sekedar rezim membentuk sosok birokrasi baru, tapi sosok baru seperti apa. Yang menjadi masalah adalah ketika standardisasi justru menghasilkan sosok birokrasi yang tidak berpikir karena tujuannya hanya sekedar mencapai standar. Rasionalisasi teknis yang diwakili oleh keberadaan standar-standar justru membuat birokrasi terbatasi pada pemenuhan standar. Ini menafikan esensi dari reformasi birokrasi itu sendiri yang menghendaki individu jadi bebas dan otonom. Jadi, kendati di awal menawarkan kebebasan yang seharusnya mensyaratkan sosok yang mampu berpikir dan berperilaku inovatifdan kreatif, tapi kenyat aannya, yang dihasilkan adalah sosok yang tidak lagi perlu berpikir karena sudah ada standar yang menent ukan apa yang harus dicapainya.

Pemahamanterhadapkonsekuensi dari setiap pilihan pendekatan reformasi birokrasi seyogianya melahirkan kesadaran yang lebih dinamis untuk merespon wacana reformasi birokrasi. Penundukkan birokrasi pada rezim pasar tidak hanya berdampak pada birokrasi, tapi juga padainstitusi-institusilainyangterlibat dalam pengelolaan urusan publik. Karena itu, pola relasi kekuasaan yang lebihkolaboratifakanlebihmendukung terwujudnya sosok birokrasi yang tidak hanya efektif dan efisien dalam mengelola sumber daya, tapi juga peka terhadap dimensi moral dan politik dalam pemenuhan kebutuhan publik.

\section{DAFTAR PUSTAKA}

Ayres, Ian \& John Braithwaite. 1992. Responsive Regulation: Transcending the Deregulation Debate. Oxford: Oxford University Press. Bank Dunia. 1989. World Development Report. New York: Oxford University Press.

Blacker, Frank, Norman Crump, dan Seonaidh McDonald. 1998. "Knowledge, Organizations, and Competition”. Dalam J. R. Georg vo Krogh, Knowing in Firms: Understanding, Managing, and Measuring Knowledge (hal. 6786). London: Sage Publications Ltd. 
Castells, Manuel. 2004. The Network Society: A Cross-cultural Perspective. UK: Edward Elgar Publishing Limited.

Cope, Glen Hahn. 1997. "Bureaucratic Reform and Issues of Political Responsiveness". Journal of Public Administration Research and Theory, Vol. 7, No. 3, hal. 461-471.

Feenberg, A. 2003. "Modernity Theory and Technology Studies: Reflections on Bridging the Gap". Dalam Misa,P. B. T. Modernity and Technology (hal. 73-104). Cambridge, Massachusetts: MIT Press.

Fritz, V. dan Rocha Menocal. 2006. (Re)building Developmental States: From Theory to Practice. London: Overseas Development Institute.

Fukuyama, Francis. 2005. StateBuilding: Governance and World Order in the Twenty-First Century. London: Profile Books.

Harris, Martin, Stewart Clegg, dan Harro Hopfl. 2011. "Introduction: Managing Modernity Beyond Bureaucracy?" Dalam Clegg, S. R. Managing Modernity: Beyond Bureaucracy? (hal.1-10).London: Oxford University Press.
Mok, Ka-Ho dan Ray Forrest. 2009. Changing Governance and Public Policy in East Asia Comparative Development and Policy in Asia Series. London dan New York: Taylor \& Francis Routledge.

Peters, B. Guy. 2002. The Politics of Bureaucracy, Fifth Edition. London and New York: Routledge.

Read, Jason. 2009. "A Genealogy of Homo-Economicus: Neoliberalism and the Production of Subjectivity". Foucault Studies(6), 25-36.

Said, M. Masúd. 2010. Birokrasi di Negara Birokratis: Makna, Masalah, dan Dekonstruksi Birokrasi Indonesia. Yogyakarta: UMM Press.

Springer, S. 2010. "Neoliberal Discursive Formations: on the Contours of Subjectivation, Good Governance, and Symbolic Violence in Posttransitional Cambodia. Environment and Planning D: Society and Space, 28, hal. 931-950.

Styhre,Alexander.2007. TheInnovative Bureaucracy: Bureaucracy in an Age of Fluidity. London: Routledge. 